\title{
Comparison of Potential Environmental Impacts on the Production of Gasoline and Kerosene, Al-Daura Refinery, Baghdad, Iraq
}

\author{
Mohammad A. Alanbari', Israa Rahman', Nadhir Al-Ansari' ${ }^{2}$, Sven Knutsson ${ }^{2}$ \\ ${ }^{1}$ College of Engineering, University of Babylon, Babylon, Iraq \\ ${ }^{2}$ Lulea University of Technology, Lulea, Sweden \\ Email: profdr_alanbari@yahoo.com, esraarahman6@gmail.com, nadhir.alansari@ltu.se, Sven.Knutsson@ltu.se
}

How to cite this paper: Alanbari, M.A., Rahman, I., Al-Ansari, N. and Knutsson, S. (2016) Comparison of Potential Environmental Impacts on the Production of Gasoline and Kerosene, Al-Daura Refinery, Baghdad, Iraq. Engineering, 8, 767-776. http://dx.doi.org/10.4236/eng.2016.811069

Received: October 17, 2016

Accepted: October 31, 2016

Published: November 3, 2016

Copyright $\odot 2016$ by authors and Scientific Research Publishing Inc. This work is licensed under the Creative Commons Attribution International License (CC BY 4.0).

http://creativecommons.org/licenses/by/4.0/

\begin{abstract}
Oil represents the main energy sources used by mankind. In addition, petroleum products serve as feedstock for several consumer goods, thus playing an important growing role in people's lives. For this reason there are various software applications designed to do the environmental assessment to see their impact on the environment. Among these is SimaPro software package designed to make a valuable contribution. It is a powerful tool for analyzing the environmental impact of products during their whole life cycle. In this study, it was applied to analyze and evaluate the impacts for Al-Daura refinery for the gasoline and kerosene fuel production. This refinery located in Baghdad, Iraq was analyzed. The results of the life cycle assessment (LCA) show that gasoline has a (single score) of the order of 11.1 point for each 1 cubic meter produce from gasoline fuel compared with 4.83 point for each 1 cubic meter produce from kerosene. Global warming, respiratory inorganics and nonrenewable energy were the most effective environmental impacts.
\end{abstract}

\section{Keywords}

Gasoline, Kerosene, Al-Daura Refinery, Refining, Baghdad, Simapro7, Life Cycle Assessment (LCA)

\section{Introduction}

Currently there is a conflict between the nature limits and the aspirations of human beings in this world [1]. Oil has numerous advantages and vitality and is fundamental for all activates related to human life; however for each phase in its life cycle it has dangers for the environmental systems, humans and wildlife [2]. 
The petroleum industry is considered as a main potential for risks on the ecosystem, and the impact is distributed on different levels: water, soil, air, and as a result all living beings on our earth [3]. The earth's natural system is gradually altered by the anthropogenic pollution where the results and impacts can have severe effects. The discharge of $\mathrm{CO}_{2}$ and other types of contaminants can generate difficult problems for the society; the most notably problem is climate change [1].

Pollution is accompanied with practically all actions throughout all phases of petrol production, from exploration actions to refining. Large amounts of aerosols, gas emissions, solid waste and wastewater are generated during the petroleum fuel production chain (drilling, production, refining and transporting) [3].

The process where unrefined petrol is treated and refined into further valuable products e.g. naphtha, gasoline, diesel, asphalt, heating oil, lamp fuel and liquefied petrol gas is referred to as oil refining or petrol refining [4] (Figure 1). Petrol refineries are commonly substantial, extensive modern structures with broad funneling running all through, conveying surges of fluids between vast concoctions preparing units. There are a few procedures required in handling unrefined inputs to make them useable and attractive fuel yields [5]. To evaluate the environmental impact of products, processes, and services, an international standard tool can be used. Life Cycle Assessment (LCA) is one of these tools, with ISO 14040. In this tool the entire life cycle is considered from raw material extraction, to manufacture, distribution, use, end of life treatment, recycling and eventually, disposal [6] [7]. In the present LCA, SimaPro 7 software was used for the inventory and database on resources consumption and environmental emissions [8]. The aim of this study is to evaluate the environmental impacts of the gasoline and kerosene fuel production. In this case Al-Daura refinery in Baghdad city, Iraq was considered.

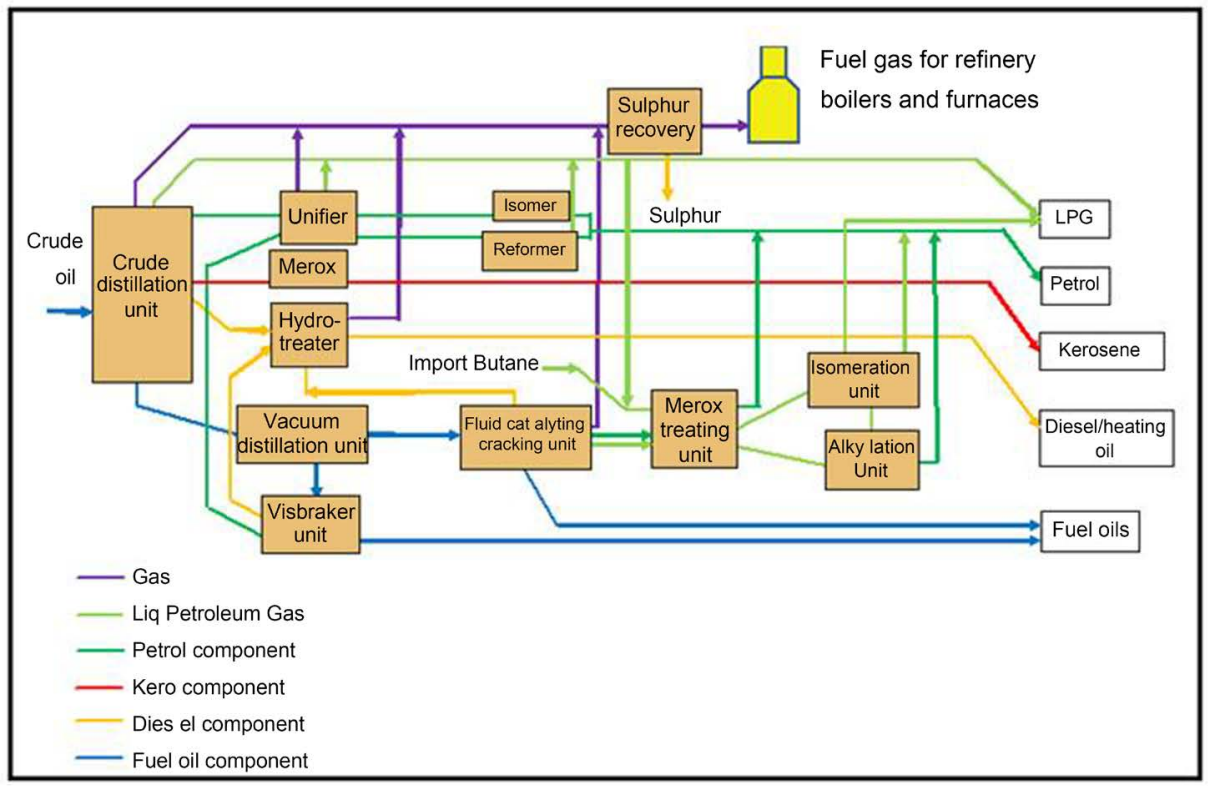

Figure 1. Typical petroleum refinery configuration [1]. 


\section{Study Area}

Baghdad is located on the River Tigris in the middle parts of Iraq and it is the capital of Iraq (Figure 2). Al-Daura Refinery) is located in Al-Daura region southeast of the capital Baghdad. It is characterized by its distinguished location on the bank of Tigris River. It covers an area of (808) acres and (47) meter about (205 Hectares) bounded from the north and west by Tigris River, from the east by the highway, and from the south by the houses of the Refinery staff. Producing capacity is currently about 210 thousand barrels per a day.

\section{Methodology}

The program SimaPro 7 (System for Integrated natural Assessment of Products), created by the Dutch PRé Consultants [6] [7], will be utilized as a life cycle assessment LCA modeling and analysis tool [9]. It manages and stores data, making calculations and sensitivity tests. In accordance with ISO14040 and ISO14044 LCA standards, LCA phases are structured in this software [10]. The main sections in the software are as follow:

1) Goal and Scope: In this section is the goal and scope are described. This can be done through:

- Different aspects of the goal and scope definition are done in this Text fields. This can be later copied and included into the report [6]. In this research gasoline and kerosene production are to be analyze and to evaluate their environmental impacts.

- Libraries with standard data which are relevant for the project can be picked in this section [6] [7]. The library of ecoinvent system processes was used in this study.

- Data characteristics can be predefined in this software [6] [7].

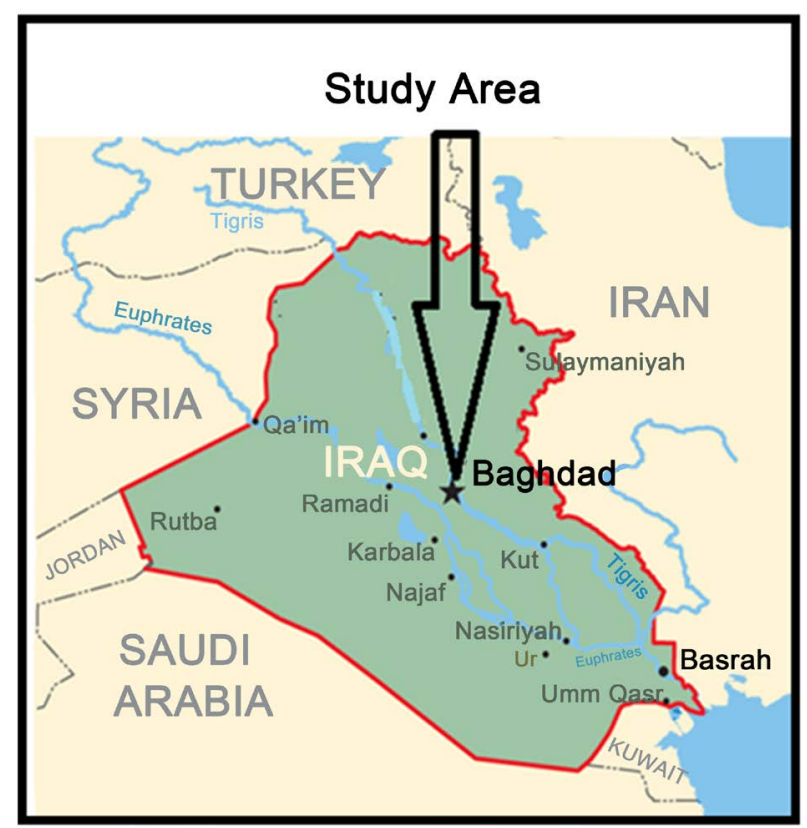

Figure 2. Location of the study area. 
2) Parameters describing resources and material uses and emission to air and water is refered to ad "Inventory Analysis". This covers the whole life cycle of the products or activities; construction; treating; sludge disposal; and all transportation involved. In the LCA a so called normalization process is used for data collection to establish a suitable data base.

3) The basic structure of impact assessment methods in this software is characterization, damage assessment, normalization and weighting and the last three steps are optional according to the ISO standards [10]. For the gasoline and kerosene environmental impacts IMPACT 2002+ method was used.

4) For interpretations, a checklist which covers the relevant issues mentioned in the ISO standards is usually used. Observations are filled in when the LCA study is in its final stages and conclusions are made [6] [7].

\section{Results and Discussion}

The results were mostly not straightforward in favor of material design over the alternative one in LCA they got to be interpreted or weighted. For product design, IMPACT $2002+$ methodology and LCA weighting method are used. It had proved to be a powerful tool for designers to aggregate LCA results into easily understandable and userfriendly numbers or units. This is called IMPACT 2002-IMPact Assessment of Chemical Toxics. The processes contributing to those impacts are detailed in Table 3.

Input consists of resources-water and crude oil for refining process, material (water, fuel oil and gas oil) for steam and electricity generation, (PDC, DMDS, and Sodium hydroxide) for production purpose.

Emission of refining process can be classified into two main groups; emission to air$\mathrm{CO}_{\mathrm{X}}, \mathrm{SO}_{\mathrm{X}}, \mathrm{H}_{2} \mathrm{O}$ and $\mathrm{NO}_{\mathrm{X}}$ which come from refining process especially from the electricity and steam generation process.

Emissions to water-BOD, COD, SO4, CL, OIL, TDS, S, SS, and Phenol. Those were wastewater (industrial wastewater) characteristics (see Figure 3 and Figure 4). For analysis the Impact $2002+$ method is used which known as a midpoint/damage approach to LCA. A user defined description of the raw materials, emissions, and energy uses associated with a particular process is entered into Simapro7, Impact 2002+ then quantifies the impacts of these steps in terms of fourteen environmental impact categories. These were also grouped into four damage categories (human health, ecosystem quality, climate change, and resources).

The fourteen environmental impact or midpoint categories in the IMPACT 2002+ are human toxicity (carcinogens and non-carcinogens), respiratory effects, ionizing radiation, ozone layer depletion, photochemical oxidation, aquatic ecotoxicity, terrestrial ecotoxicity, terrestrial acidification/nitrification, aquatic acidification, aquatic eutrophication, land occupation, global warming, non-renewable energy and mineral extraction. While the damage categories are human health, ecosystem quality, climate change and resources. Figure 5 shows linking LCI results via the midpoint categories to damage categories. 


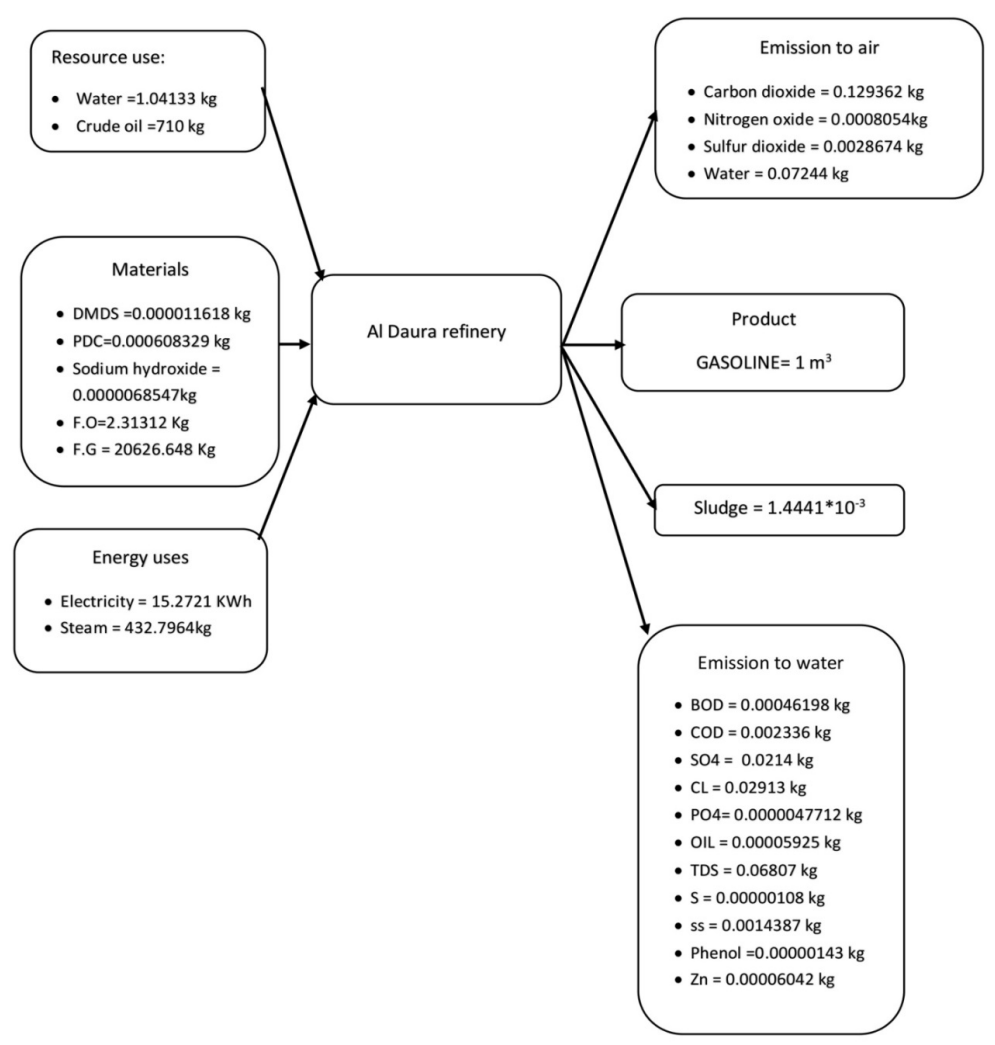

Figure 3. Inventory analysis of gasoline.

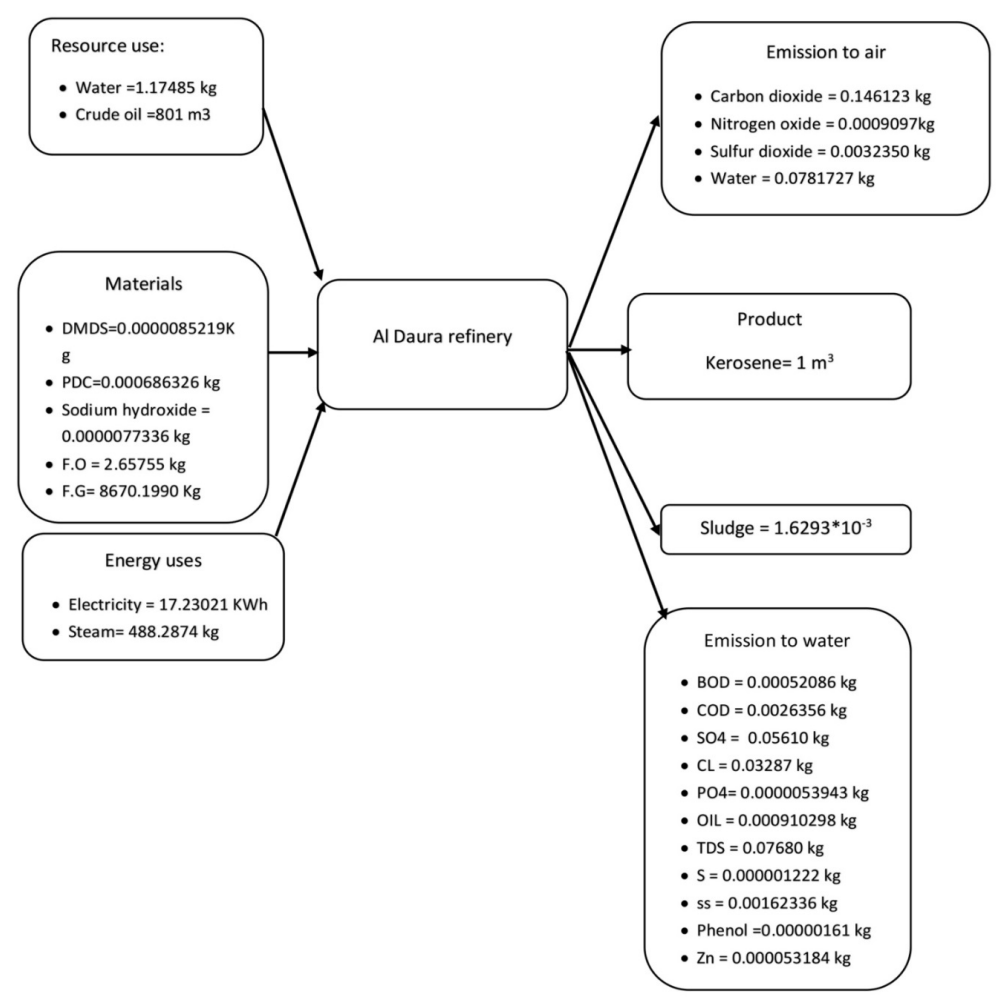

Figure 4. Inventory analysis of kerosene. 


\subsection{The Single-Score in Terms of Impact Categories (Midpoints) of Al-Daura Refinery}

Figure 6 shows the single-score in terms of impact categories of Al-Daura refinery. Non-renewable energy, respiratory inorganic and global warming, contributing to the two products were the most environmentally potential. As shown in Figure 6 and Table 1, gasoline impact was higher than kerosene, the total single score of gasoline was equal to $11.1 \mathrm{Pt} / \mathrm{m}^{3}$ of gasoline compare to kerosene of $4.83 \mathrm{Pt} / \mathrm{m}^{3}$ of kerosene.

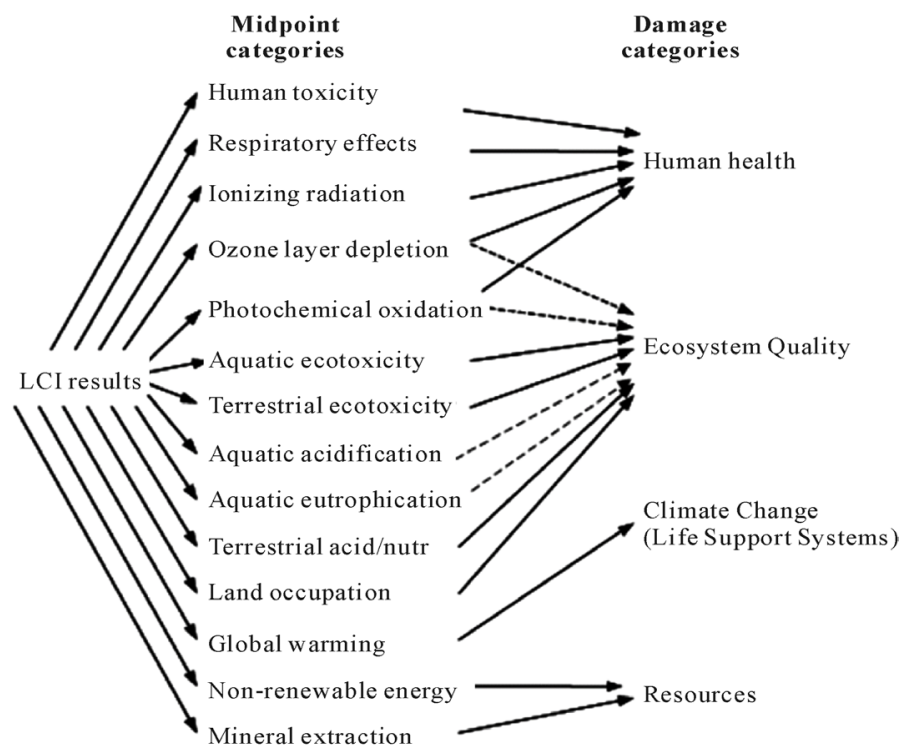

Figure 5. Overall scheme of the impact 2002+ framework, linking LCI results via the midpoint categories to damage categories. Based on [6] [7].

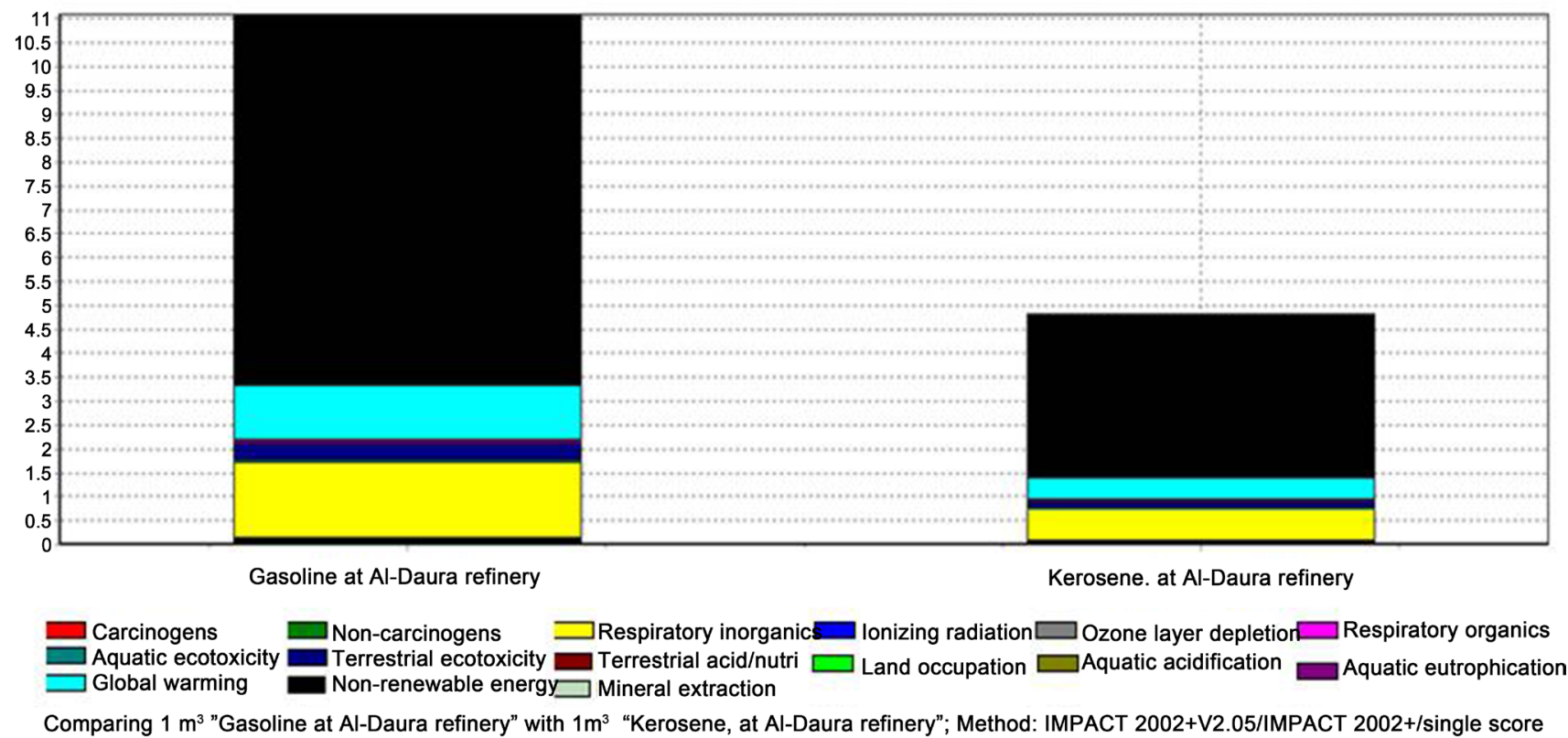

Figure 6. Single score in terms of impact categories of Al-Daura refinery. 
Table 1. Single score in term of impact categories of Al-Daura refinery.

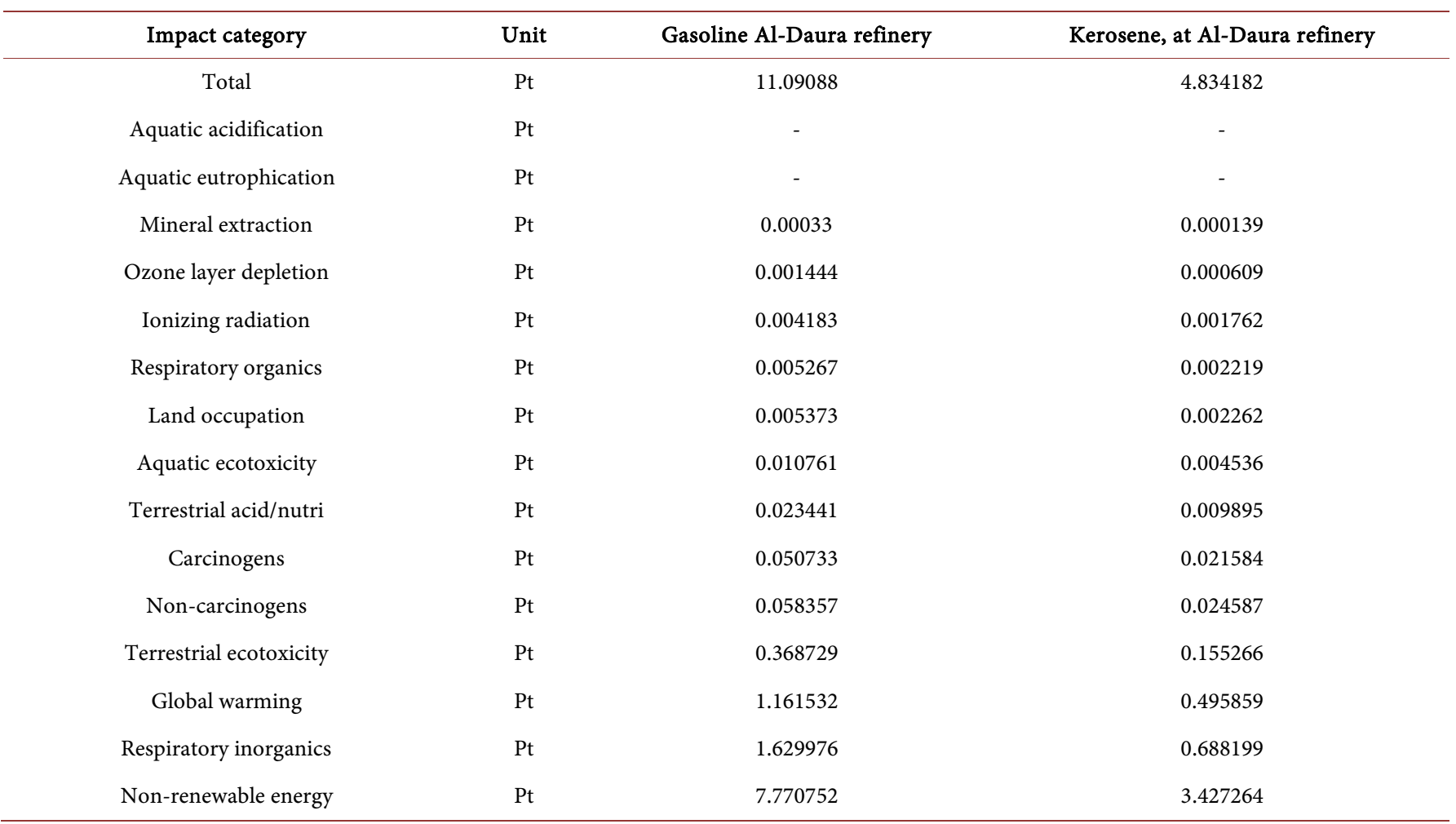

\subsection{Single Score in Term of Damage Categories of Al-Daura Refinery}

IMPACT 2002+ was used to analyze the damage categories. Human health, Ecosystem quality, Climate change and Resources were found to be considered as damage categories (Table 2). Also Figure 7 show the single score in term of damage categories of AlDaura refinery. According to Figure 7, Human Health, and Climate change are much more important than the damage on Ecosystem Quality. Gasoline total damage was equal to $(11.1 \mathrm{Pt})$, compare to kerosene $(4.83 \mathrm{Pt})$, the total refining damage categories are shown in Table 2.

\subsection{Contribution Analysis}

Contribution analysis is a significant tool used to understand the uncertainty of results. This analysis help in determine the process of significant role in your result. Frequently we have a LCA consists of hundreds different process, but indeed $95 \%$ - 99\% of results are related to just ten processes, so when using contribution analysis we can focus our attention on these processes.

The contribution analysis ways in SimaPro are two as follow:

1) Contribution analysis section of the result screen (see Table 3 ).

2) Graphical representation of the process tree or network: the relative contribution of each procedure can be evaluated by using the tree procedure. This methodology has benefit represented in getting the exact role of the procedure in the life cycle (Figure 8 and Figure 9). 


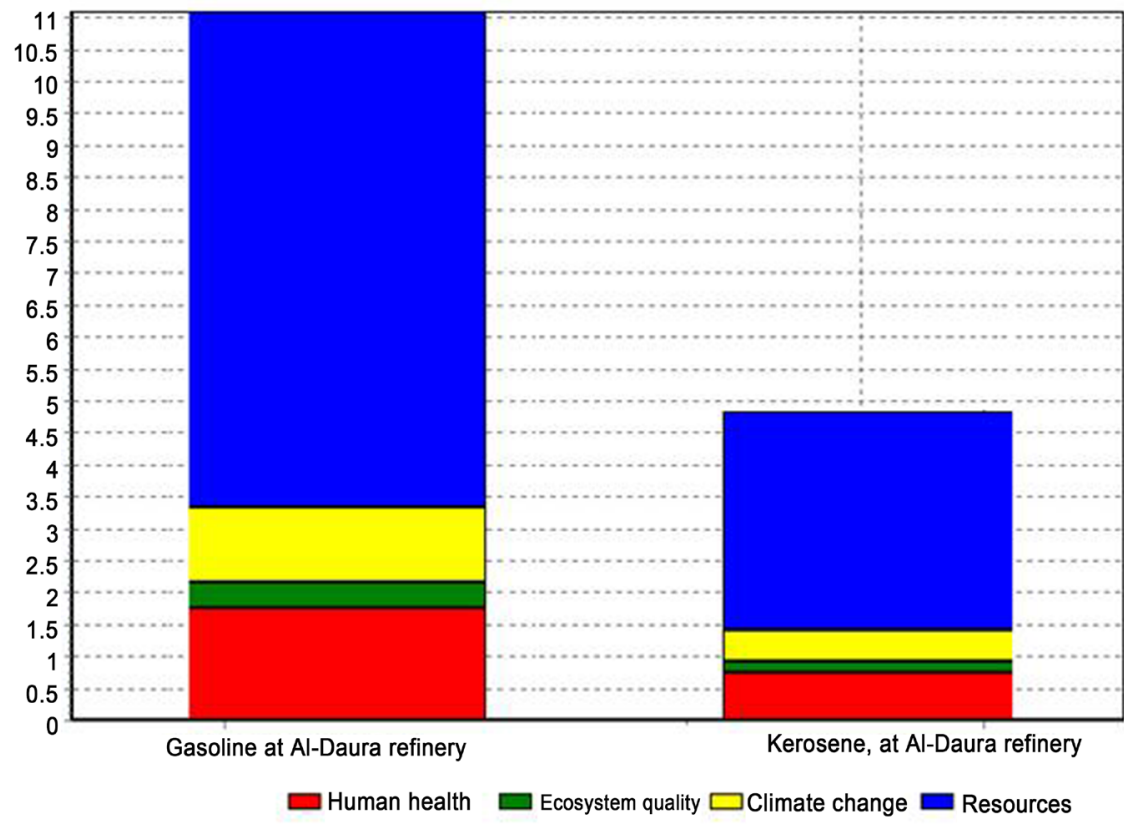

Comparing $1 \mathrm{~m}^{3}$ "Gasoline at AI-Daura refinery" with $1 \mathrm{~m}^{3}$ "Kerosene, at Al-Daura refinery"; Method: IMPACT 2002+V2.05/IMPACT 2002+/single score

Figure 7. Single score in term of damage categories.

Table 2. Single score in term of damage categories.

\begin{tabular}{cccc}
\hline Damage category & Unit & Gasoline at Al-Daura refinery & Kerosene, at Al-Daura refinery \\
\hline Total & $\mathrm{Pt}$ & 11.09088 & 4.834182 \\
Ecosystem quality & $\mathrm{Pt}$ & 0.408304 & 0.171959 \\
Climate change & $\mathrm{Pt}$ & 1.161532 & 0.495859 \\
Human health & $\mathrm{Pt}$ & 1.749961 & 0.73896 \\
Resources & $\mathrm{Pt}$ & 7.771082 & 3.427403 \\
\hline
\end{tabular}

Table 3. Process contribution.

\begin{tabular}{cccc}
\hline Process & Unit & Gasoline at Al-Daura refinery & Kerosene, at Al-Daura refinery \\
\hline Total of all processes & $\mathrm{Pt}$ & 11.09088 & 4.834182 \\
Refinery gas, at refinery/RER S & $\mathrm{Pt}$ & 10.84757 & 4.559665 \\
Gasoline at Al-Daura refinery & $\mathrm{Pt}$ & 0.214015 & - \\
Steam, for chemical processes, at plant/RER S & $\mathrm{Pt}$ & 0.025943 & 0.002227 \\
Electricity, at refinery/RER S & $\mathrm{Pt}$ & 0.001124 & 0.029269 \\
Heavy fuel oil, at regional storage/RER S & $\mathrm{Pt}$ & $3.57 \mathrm{E}-07$ & 0.001291 \\
Carbon tetrachloride, at plant/RER S & $\mathrm{Pt}$ & $5.09 \mathrm{E}-08$ & $4.03 \mathrm{E}-07$ \\
Disposal, refinery sludge, 89.5\% water, to sanitary landfill/CH S & $\mathrm{Pt}$ & $7.02 \mathrm{E}-09$ & $5.74 \mathrm{E}-08$ \\
Dimethyl sulphate, at plant/RER S & $\mathrm{Pt}$ & $2.49 \mathrm{E}-09$ & $5.15 \mathrm{E}-09$ \\
Sodium hydroxide, $50 \%$ in $\mathrm{H}_{2} \mathrm{O}$, production mix, at plant/RER S & $\mathrm{Pt}$ & - & $2.81 \mathrm{E}-09$ \\
Kerosene, at Al-Daura refinery & $\mathrm{Pt}$ & 0.241445 & \\
\hline
\end{tabular}




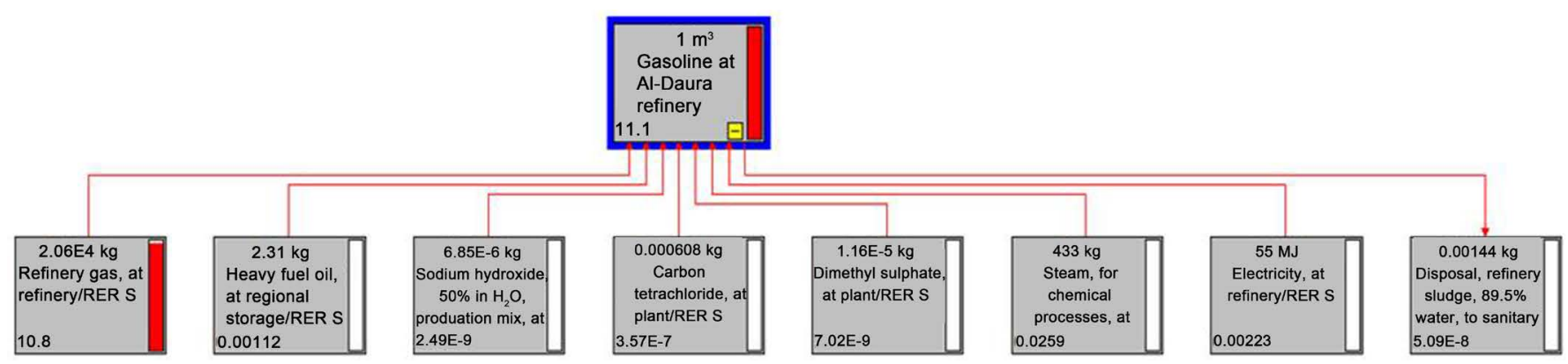

Figure 8. Process contribution of gasoline.

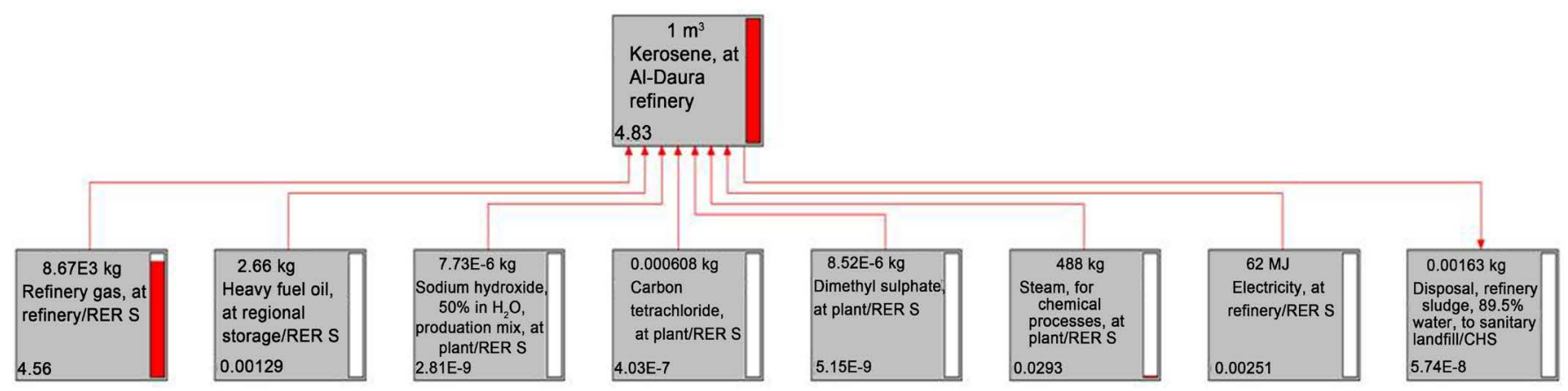

Figure 9. Process contribution of kerosene.

\section{Conclusion}

In this research, Simapro7 software was used to evaluate environmental indicators for gasoline and kerosene production in Al-Daura refinery. For this purpose, the IMPACT $2002+$ was applied. The results indicated that the single-score on gasoline production was 11.1 Pt compared with 4.83 Pt for kerosene. The most environmental impact potential was global warming, respiratory in organics and non-renewable energy.

\section{References}

[1] Born, R.O. (2012) From Ground to Gate: A Lifecycle Assessment of Petroleum Processing Activities in the United Kingdom. Department of Energy and Process Engineering, Norwegian University of Science and Technology.

[2] Epstein, P.R. and Selber, J. (2002) Oil a Life Cycle Analysis of Its Health and Environmental Impacts. The Center for Health and the Global Environment Harvard Medical School.

[3] Jacqueline \& Emilio. Environmental Impacts of the Oil Industry. UNESCO-ELOSS. http://www.eolss.net/Eolss-sampleAllChapteraspx

[4] Gary, J.H. and Handwerk, G.E. (1984) Petroleum Refining Technology and Economics. 2nd Edition, Marcel Dekker, Inc.

[5] Leffler, W.L. (1985) Petroleum Refining for the Nontechnical Person. 2nd Edition, Penn Well Books.

[6] PRé Consultants (2010) Introduction to LCA with SimaPro 7. http://www.environmental-xpert.com/software/pre/pre.htm

[7] PRé Consultants (2016) Introduction to LCA with SimaPro. www.pre-sustainability.com/download/SimaPro8IntroductionToLCA.pdf 
[8] Al-Daura Refinery Records (2015) Ministry of Oil, Baghdad.

[9] Notarnicola, B., Salomone, R., Petti, L., Renzulli, P.A., Roma, R. and Cerutti, A.K. (2015) Life Cycle Assessment in the Agri-Food Sector: Case Studies, Methodological Issues. Springer International Publishing Switzerland. http://dx.doi.org/10.1007/978-3-319-11940-3

[10] Akwo, N.S. (2008) A Life Cycle Assessment of Sewage Sludge Treatment Options. Department of Development and Planning Aalborg University.

Submit or recommend next manuscript to SCIRP and we will provide best service for you:

Accepting pre-submission inquiries through Email, Facebook, LinkedIn, Twitter, etc.

A wide selection of journals (inclusive of 9 subjects, more than 200 journals)

Providing 24-hour high-quality service

User-friendly online submission system

Fair and swift peer-review system

Efficient typesetting and proofreading procedure

Display of the result of downloads and visits, as well as the number of cited articles

Maximum dissemination of your research work

Submit your manuscript at: http://papersubmission.scirp.org/

Or contact eng@scirp.org 